This item was submitted to Loughborough's Research Repository by the author.

Items in Figshare are protected by copyright, with all rights reserved, unless otherwise indicated.

\title{
Meeting the needs of industry: the drivers for change in engineering education
}

PLEASE CITE THE PUBLISHED VERSION

http://www.ee2010.info/

\section{PUBLISHER}

(c) Higher Education Academy Engineering Subject Centre, Loughborough University

VERSION

VoR (Version of Record)

\section{LICENCE}

CC BY-NC-ND 4.0

\section{REPOSITORY RECORD}

Arlett, Carol J., Fiona M. Lamb, Richard Dales, Liz Willis, and Emma E. Hurdle. 2019. "Meeting the Needs of Industry: The Drivers for Change in Engineering Education". figshare. https://hdl.handle.net/2134/9414. 
This item was submitted to Loughborough's Institutional Repository (https://dspace.lboro.ac.uk/) by the author and is made available under the following Creative Commons Licence conditions.

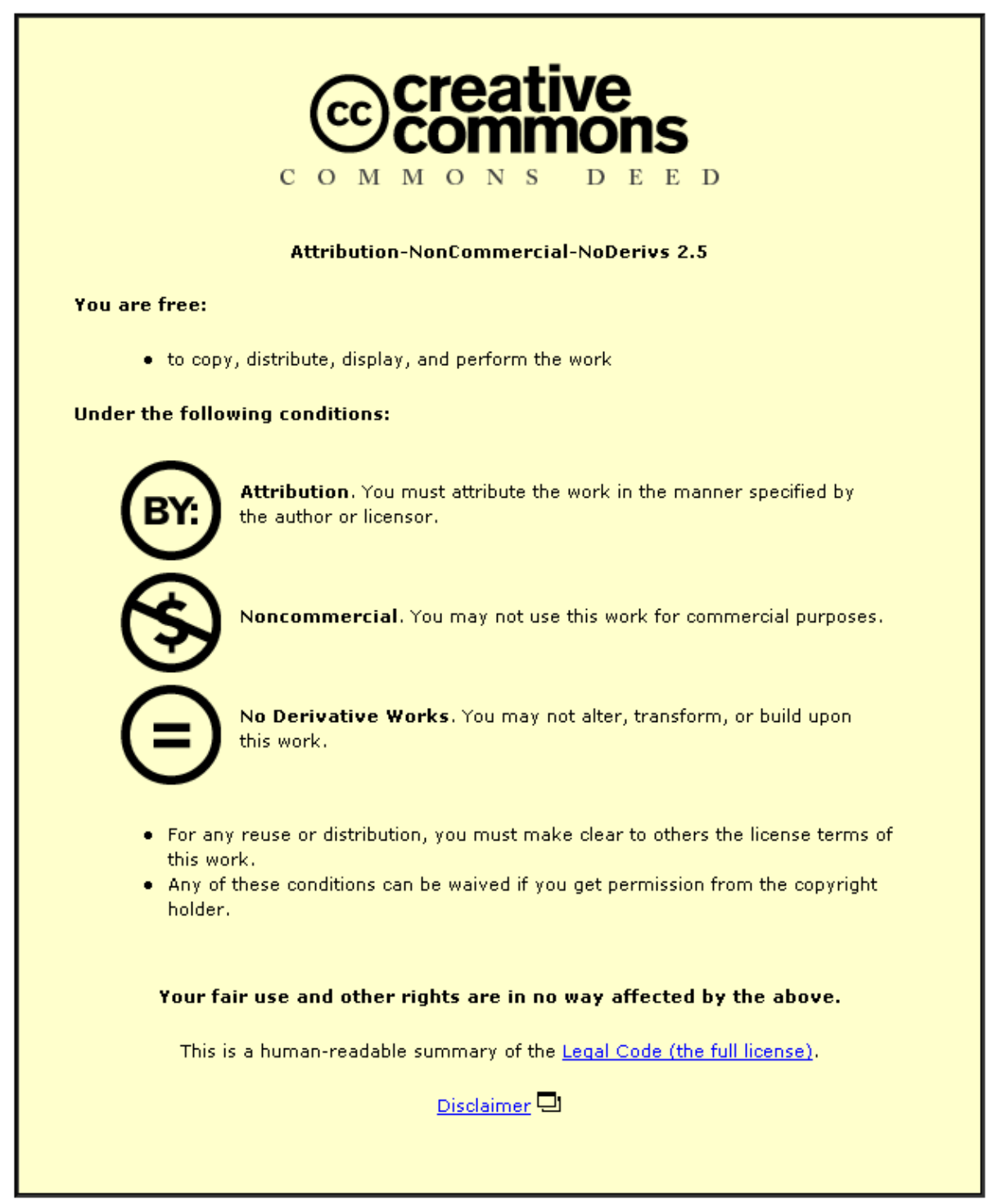

For the full text of this licence, please go to: http://creativecommons.org/licenses/by-nc-nd/2.5/ 


\title{
Meeting the needs of industry: the drivers for change in engineering education
}

\author{
Carol Arlett (carol@engsc.ac.uk), Fiona Lamb, Richard Dales, Liz Willis, Emma Hurdle
}

\author{
Engineering Subject Centre, Loughborough University, UK
}

\begin{abstract}
This paper examines the drivers for change as engineering departments develop 'experience-led degrees' that aim to equip students with the employability skills needed by industry. The term 'experience-led engineering degree' came from the Sainsbury Review and is taken to mean components of an engineering degree that develop industry related skills and which may also include industry interaction.
\end{abstract}

It presents the relevant findings from a study on how engineering degrees meet the needs of industry (Engineering graduates for industry). The study used a case study approach to address the research question: "How can we enhance a sustainable world-class higher education engineering sector that meets the graduate recruitment needs of industry?" Six case studies were developed that describe examples of experience-led components in engineering departments across England.

A number of key messages emerged from the analysis of the case studies and this paper looks in detail at the drivers that lead to change within universities and discusses how these vary according to institutional missions and priorities. The case studies demonstrated examples of both wide-scale radical change and incremental small-scale change, with all cases showing the vital role played by learning and teaching champions in driving forward change at a departmental level and the importance of support from senior management. It is also recognised that responsibility for change must be shared between universities, industry and the funding bodies. Barriers to change have been identified and recommendations are made as to how change can be facilitated.

\section{Introduction}

'Engineering graduates for industry' was commissioned by the Department for Innovation, Universities and Skills - now the Department for Business, Innovation and Skills (BIS) - following a recommendation made by Lord Sainsbury of Turville in his review of the Government's Science and Innovation policies (Lord Sainsbury 2007) to: “... review current approaches to engineering education ... [and] develop, with a number of leading engineering universities, an experience-led engineering degree ...".

The principal objective of the study was to take the findings and recommendations from the Royal Academy of Engineering's Educating Engineers for the 21st Century (EE21C) report (The Royal Academy of Engineering 2007), which examined the needs of industry in depth, and to build on this to identify effective practices within current and developing experience-led engineering degrees that meet these needs. Note that the term 'Experience-led engineering degree' in this paper is understood to be an engineering degree that develops industry related skills and that may also include industry interaction.

A case study approach was used to provide an in-depth examination of experience-led engineering activity in six English universities. The approach examined the opportunities, barriers and costs (as far as possible) involved with curriculum change. This included the differing perspectives of the main stakeholders, for example, students, graduates, employers and all necessary staff groups (academic, learning and teaching, and support). The study also examined Destinations of Leavers from Higher Education (DHLE) data provided by Higher Education Statistics Agency (HESA) on first jobs on 
graduation. Recommendations in the study's report on how these outcomes can be implemented to enhance future engineering degrees have been submitted to government, universities and industry.

[The case study research was undertaken by the Engineering Subject Centre through the Royal Academy of Engineering and directed by an Oversight Group, initially chaired by Lord Browne of Madingley and then by Professor Sir William Wakeham, comprising senior engineering academics, industrialists, professional affiliates and government representatives.]

\section{Research questions}

The study initially identified a key research question, derived from the study brief:

How can we enhance a sustainable world-class higher education engineering sector that meets the graduate recruitment needs of industry?

This led to a further six subsidiary research questions:

1. What does industry need from HE engineering graduates?

2. How do universities know what industry needs?

3. What are universities currently doing, or developing, within their teaching that meets these needs of industry, and why?

4. What difference are these activities making?

5. What more/else could be done to better enable universities working together with industry to meet these needs in the future?

6. How can universities and industry cooperate effectively and be best supported in this process?

\section{Methodology}

The first two of these subsidiary research questions were addressed primarily through existing literature, in particular the EE21C report, but also all relevant and recent UK and international publications. The research questions were used to frame the structure of over 85 in-depth interviews that were conducted with academic staff, students, industrialists, graduates and other relevant university units (e.g. staff support) at the six case study universities.

In addition to the interviews, the study team used a wide range of sources to provide additional evidence and for validation purposes. These included internal institutional documents, published papers, marketing materials, HESA, student satisfaction data, accreditation reports, external examiner reports and programme reviews.

The universities were selected to cover a broad range of university types, geographical location (within England), engineering disciplines and range of industrial activity/involvement/skills developed. In consultation with university staff, examples of effective practice in experience-led engineering education were selected for in depth analysis at each case study institution. All cases were only focused on engineering departments and undergraduate studies. The six universities selected for case studies are shown in Table 1. which summarises the disciplines covered and illustrates the 15 experience-led exemplars of effective practice selected. The detailed case studies are available from the Engineering Subject Centre website, www.engsc.ac.uk/graduates-for-industry.

The study report "Engineering Graduates for Industry" (Lamb et al, 2010) presents a summary of the key findings in answer to the above research questions. This paper addresses in more detail the answers to why universities are making changes to their teaching (question 3 ) and how can this be supported (question 6) as they relate to the management of change. It discusses the drivers for change, the nature of change, the change agents and the barriers to change, as well as making recommendations on how change can be facilitated.

\section{Relevant findings relating to the management of change One size doesn't fit all}

The six universities examined in this study differ in many ways. Relevant factors include geographical location, research or teaching led, vocational or academic focus, nature of the student cohort and the history of/mission for industrial engagement. As a result, each university has its own identity, attracting students from differing backgrounds (in terms of qualifications, age, part-time/full-time, workbased and socio-economic background). Each university and engineering department also seeks to produce graduates with a particular mix of skills, knowledge and experience to suit specific areas of 
the graduate jobs market (Confederation of British Industry (CBI) 2009). As a consequence, each university needs to be able to take its own approach to developing and embedding experience-led components.

\section{Table 1. Summary of case study institutions}

\begin{tabular}{|c|c|c|c|}
\hline University & Faculty/School & $\begin{array}{l}\text { Engineering disciplines } \\
\text { covered in this study }\end{array}$ & Exemplars \\
\hline Aston University & $\begin{array}{l}\text { School of } \\
\text { Engineering and } \\
\text { Applied Science }\end{array}$ & $\begin{array}{l}\text { Chemical, Computer } \\
\text { Science, Electronic, } \\
\text { Engineering Systems and } \\
\text { Management, Mechanical }\end{array}$ & $\begin{array}{l}\text { 1. Industrial placements } \\
\text { 2. Foundation degrees in power } \\
\text { engineering }\end{array}$ \\
\hline Coventry University & $\begin{array}{l}\text { Faculty of } \\
\text { Engineering and } \\
\text { Computing }\end{array}$ & $\begin{array}{l}\text { Aerospace, Automotive, } \\
\text { Built Environment, Civil, } \\
\text { Computing, Electronic, } \\
\text { Knowledge Management, } \\
\text { Mechanical }\end{array}$ & 3. Activity led learning \\
\hline $\begin{array}{l}\text { Imperial College } \\
\text { London }\end{array}$ & $\begin{array}{l}\text { Faculty of } \\
\text { Engineering }\end{array}$ & $\begin{array}{l}\text { Aeronautics, } \\
\text { Bioengineering, Chemical, } \\
\text { Civil, Computing, Electrical, } \\
\text { Electronic, } \\
\text { Environmental, Materials, } \\
\text { Mechanical }\end{array}$ & $\begin{array}{l}\text { 4. Industrial simulation } \\
\text { (Constructionarium and chemical } \\
\text { pilot plant) } \\
\text { 5. Discipline-based support (enVision) } \\
\text { 6. Large group projects } \\
\text { 7. Student-led activities }\end{array}$ \\
\hline $\begin{array}{l}\text { University of } \\
\text { Liverpool }\end{array}$ & $\begin{array}{l}\text { Faculty of } \\
\text { Engineering }\end{array}$ & $\begin{array}{l}\text { Aerospace, Civil, Materials } \\
\text { Science, Mechanical }\end{array}$ & $\begin{array}{l}\text { 8. Active learning (adapted from } \mathrm{CDIO} \text { ) } \\
\text { 9. Visiting professors }\end{array}$ \\
\hline $\begin{array}{l}\text { London South Bank } \\
\text { University }\end{array}$ & $\begin{array}{l}\text { Faculty of } \\
\text { Engineering, } \\
\text { Science and The } \\
\text { Built Environment }\end{array}$ & $\begin{array}{l}\text { Applied Sciences, } \\
\text { Engineering and Design, } \\
\text { The Built Environment, } \\
\text { Urban Engineering }\end{array}$ & $\begin{array}{l}\text { 10. Understanding stakeholder needs } \\
\text { 11. 'Live' experimental laboratory } \\
\text { (CEREB) }\end{array}$ \\
\hline $\begin{array}{l}\text { Loughborough } \\
\text { University }\end{array}$ & $\begin{array}{l}\text { Faculty of } \\
\text { Engineering }\end{array}$ & $\begin{array}{l}\text { Aeronautical, Automotive, } \\
\text { Building, Chemical, Civil, } \\
\text { Electrical, Electronic, } \\
\text { Manufacturing, Mechanical }\end{array}$ & $\begin{array}{l}\text { 12. Industrial placements (Diploma in } \\
\text { Industrial Studies) } \\
\text { 13. Industrial group projects (Teaching } \\
\text { Contract Scheme) } \\
\text { 14. Sponsored degree programmes } \\
\text { 15. Discipline-based support (engCETL) }\end{array}$ \\
\hline
\end{tabular}

\section{Drivers for Change}

A detailed analysis of the case studies found that there was some commonality across the universities and these were consistent with the views of de Graff and Kolomos (de Graaff, Kolmos 2007) who reported that across the globe the shift to project and problem-based learning (PBL) was caused by wishes to:

- decrease drop-out rates;

- stimulate motivation for learning;

- accentuate institutional profile;

- support development of new competences.

These points are illustrated by the following examples from the case studies:

- At Liverpool, changes were seen as essential to improving retention on engineering courses, increasing the quantity and improving the quality of undergraduate recruits.

- Activity based approaches are being introduced at Coventry to create an environment that motivates students and one in which students want to learn.

- All the universities wanted to ensure their engineering programmes were relevant to the $21^{\text {st }}$ Century and wanted to establish (or maintain) an international reputation for high quality professionally-focused graduates.

- Demands from employers for graduates with better employability skills has led to the introduction of more practical hands-on activities in the courses and simulated industrial experience such as Constructionarium, Pilot Plant and Formula Student (a world-wide competition for students to design, build, develop, market and compete as a team with a racing car). Industrial placements are seen by Loughborough as a key means to making students who are more employable. 
An additional driver for change is the changing nature of the student population with an increase in the number of work-based students. Some of the universities (London South Bank (LSBU) and Coventry) already have a long-standing dedication to supporting part-time students, many of whom are in work.

The current economic down turn and the changing nature of manufacturing is becoming a driver for change. For example, Aston has long-established relationships with local industry, but the traditional industries in the West Midlands are disappearing. Consequently, Aston is nurturing relationships with local small and medium-sized enterprises (SMEs). They are aiming to develop students' design and innovation capabilities as well as encourage entrepreneurship activities.

Some universities reported that changes to programmes were directly driven by the skills gaps in particular sectors and new courses have emerged as part of strategic moves towards new or niche markets. For example: the Department of Materials at Imperial has developed courses in bio-materials and nuclear; LSBU and Aston have both developed Foundation degrees in power engineering and Loughborough has sponsored degree programmes to produce high quality manufacturing engineering graduates. These examples of vocationally-based Foundation degrees demonstrate how universities are already responding to the UK government's demand for greater diversity in models of learning (Department for Business Innovation and Skills 2009).

Many examples of developments in engineering education have resulted from serendipity, often through chance associations of individuals. A key example from the case studies was the initial development of 'Constructionarium' by Imperial College (Wise, McCann, 2005). Processes, such as 'visiting professor' schemes, that encourage serendipitous associations of individuals from diverse backgrounds and from which novel experiential educational approaches might develop should be strongly promoted. Additionally, there is an associated need for having educational support frameworks in place that work to capture, enhance, safeguard and disseminate any novel approaches that emerge.

\section{Nature of change}

The case studies provide examples of radical change with step-changes to the content and mode of delivery of the curriculum and the development of new degree programmes, as well as incremental change with small scale innovations and improvements. The analysis of the case studies shows that the way in which change towards a more experience-led approach occurs depends significantly on the institutional ethos, in particular with regard to industry. Universities with industrial engagement embedded strongly in their institutional mission often have ongoing incremental change while others might go through less frequent but more radical change, often triggered when a department or faculty has 'stood still' for a while or ongoing incremental change becomes insufficient.

The engineering education literature tends to focus on examples of radical educational change. For example, the adoption of the Conceive-Design-Implementation-Operate (CDIO) approach to improving teaching and learning requires major changes to the content and delivery of the curriculum and "universities are resistant to change as a matter of organizational design and tradition" (Crawley et al. 2007:168) . In their book on 'Management of Change' (de Graaff, Kolmos 2007) de Graff and Kolomos address issues faced by engineering departments who go through complicated transformational processes from traditional teaching systems to PBL systems.

Examples of radical change found in the case studies include the introduction of new pedagogic approaches such as activity based learning, sponsored programmes or the adoption of educational frameworks such as CDIO, which aim to create an environment that motivates and engages students. The case studies show that radical change can bring large scale benefits, such as coherence across programmes, opportunities for efficiency gains and good use of capital spend.

There are also benefits of incremental change as this can allow a faster response to changing needs, enabling departments to keep ahead of the game and taking advantage of opportunities as they arise. The literature on the debate of radical versus incremental innovation in education is summarised by McKenzie (McKenzie et al. 2005). Also, whilst some authors believe that it is not possible to make major changes through small changes to existing products and processes, others argue that innovation implemented with only minor adaptations of existing routines, can have long lasting consequences. Examples of incremental change in the case studies include the development or enhancement of experience-led components such as large group projects, student led activities, visiting professors, innovative teaching facilities and industrial group projects.

Three types of changes are described in the JISC InfoKit (JISC infoNet Service ): 
- developmental (incremental, enhances existing aspects of an organisation, may be planned or emergent);

- $\quad$ transitional (radical, seeks to achieve a desired state that is different from the existing one); and

- transformational (results in an organisation that is significantly different and continuously learns, adapts and improves).

Examples of change within the case studies would mainly fall within the first two of these categories.

There are many models and theories for change. The experiences of the case study institutions show that the choice of model and the process for change has to fit the purpose and the specific needs, culture and mission of each organisation. When considering the change management literature it is worth noting that within the context of higher education, the product of a change process is not a new tangible product, but is about the students' knowledge and competencies (de Graaff, Kolmos 2007). However, changes to the curriculum that involve moving to more active and collaborative learning, which may involve workspaces, staffing and funding, will always benefit from a systematic approach to change management (McCartan et al. 2008).

\section{Change roles}

The case studies demonstrate that change will not occur if the right support is not in place across the organisation. This section outlines the different roles that contribute to the implementation of change.

\section{Leadership}

Effective change must be aligned with institutional strategy and integrated into business plans, hence this requires support from senior management. Each case study was able to clearly identify where and how senior management played an important role, often highlighting the impact of particular individuals. However, these leaders were not always part of the institution's senior management, but in some cases were senior within faculties or departments.

\section{Change agents}

The case studies are based on interviews with engineering academics, many of whom had been involved with implementing change at a local level in a 'middle-manager' role - but possibly would not have seen themselves as 'change agents'. However it is evident that this group of staff (including Learning and Teaching Co-ordinators and Programme Directors) are critical to making things happen by monitoring progress, overcoming barriers and gaining commitment from other academic staff.

\section{Educational support}

Discipline specific support is valued by engineering academics both at a local and national level. The engCETL at Loughborough and EnVision at Imperial both provide direct support for engineering academics. They offer funding for projects, undertake educational research and seek to ensure that engineering education is rewarded. Although Coventry and Liverpool do not have dedicated centres, they have dedicated teaching support within engineering. For successful change, having some discipline specific support can be recognised as a success factor. The benefits of support at this level are that teaching resources can be developed in a co-ordinated manner and transferable projects are identified.

At Coventry University, curriculum design changes have been made with support from the national Higher Education Academy Engineering Subject Centre, who made visits and ran a range of workshops for staff.

\section{Change champions}

The dedication of individual members of staff, who do not necessarily have a management role, is critical to introducing experience-led components into the curriculum. Learning and teaching champions, who are early adopters of change and want to see improvements to the student learning experience, play a vital role in driving forward change within engineering programmes. The study team observed how the enthusiasm of these 'change champions' helped to act as catalysts and support colleagues through the change process. These are the innovators in departments who "create, adopt and adapt, but they do not necessarily see themselves as promoting original ground breaking change." (Hannan and Silver 2002:2) It was also noted that these champions are not always recognised and rewarded by their own universities.

Champions can come from outside of the university, for example alumni are actively used by some engineering departments to drive change. Also Visiting Professors and Visiting Teaching Fellows are 
industrialists who spend time in universities (under initiatives run by the Royal Academy of Engineering) to be role models for the profession and to enrich the learning experience for students by providing real-life problems and experiences.

\section{Change participants}

Changes to experience-led degrees have an affect on different groups of participants including staff, students and industry.

1. Staff: Experiences from the case study institutions indicate that, not surprisingly, the more radical the change, the harder it can be to bring staff along with that change. The change management literature (de Graaff and Kolmos 2007, Trowler, Saunders \& Knight 2003) highlights the need to engage key stakeholders at all points in the process and the need to plan for staff development for the change to be effective and embedded.

2. Industry and employer organisations: All the case study universities want their courses to have industrial relevance and satisfy the requirements of their industrial partners - and recognise that they needed to build on existing partnerships (through research, knowledge transfer or teaching) to increase the input from industry.

3. Students: Student engagement is critical to the success of changes to the curriculum and they need to be aware of the potential benefits. The unwillingness of students to take up available optional opportunities (including placements) is a concern expressed by some of the case study universities. However, the case studies demonstrate ways that students are engaged through initiatives and competitions, such as Formula Student, both as extra-curricula activity and as part of their degree programmes.

At an incremental level, changes can be made to existing methods of curriculum delivery such as using real-world engineering examples during lectures. (Collins, Davies 2009) analysed student essays on 'What makes a good engineering lecturer?' found a strong consensus that industrial experience was highly valued by students.

\section{Overcoming barriers to change}

The role of academic staff is critical to providing students with experience-led degree programmes. However, in recent years, the number of academic staff with prior experience in industry has been declining, particularly in research-led universities and the study team has found concerns about the ability of staff to deliver experience-led teaching. However, mechanisms are in place that enable academics to gain insight into industry such as: collaborating with engineers in industry on student projects; research collaboration with engineers from industry; academic secondments into industry and bringing engineers from industry into universities to support teaching.

Establishing effective working relationships between industry and academia is not without its problems. Developing a shared understanding is critical and requires overcoming differences in culture and language; taking time, effort and commitment (Arlett, Dales 2008). Communication needs to be two-way and not only do universities need to understand the priorities and drivers of industry, but industry needs to adapt to strategic and operational drivers of academia and have an appreciation of the needs of the new graduates they recruit.

Changes to engineering degrees in the UK must meet requirements for quality as set by universities and external bodies such as the Quality Assurance Agency, professional standards for accreditation and the compatibility of qualifications within a common educational framework in Europe as indicated by the Bologna Declaration Process (The European High Education Area 1999). The accreditation by professional bodies is often perceived to be a barrier to innovation. However, the process can be used to encourage the adoption of experience-led components. For engineering courses, the Accreditation Standard (Engineering Council UK 2008 (first published 2004)) gives universities freedom to plan and resource programmes, provided they achieve the required outcomes.

New teaching methodologies require appropriate learning spaces, equipment and supporting technologies - all of which require capital and recurrent funding. In the current economic climate, it is unrealistic to expect an increase in funding. However, collaborative activities and facilities shared between universities and colleges, or with industry, could make more efficient use of resources.

The case studies clearly demonstrate that the successful delivery of experience-led components within engineering degrees depends on a strong tripartite relationship between staff, students and industry (see Figure 1). The three-way interactions impact directly on both teaching and curriculum development. 


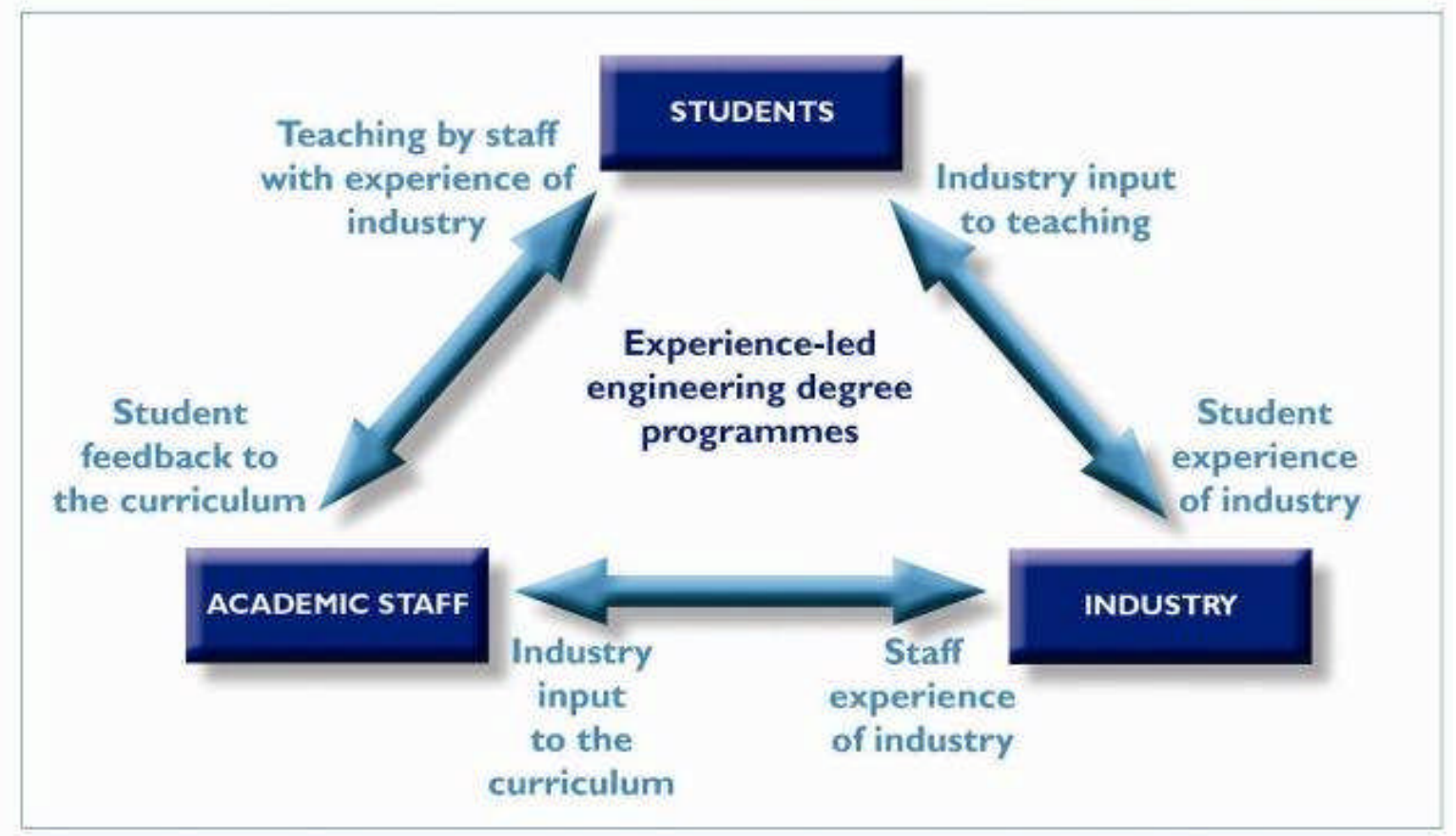

Figure 1. Relationships between academic staff, students and industry for experience-led engineering degree programmes

These relationships work in unique ways within each university and the case studies reveal resulting variations in the scale and impact of the experience-led activities on offer.

\section{Conclusion and recommendations}

Each university is different and needs to take a different approach to achieving change, whether it is radical or incremental in nature. However, there are some common drivers for change and various roles that are essential for the implementation of the change process. The case studies reveal some elements that are crucial to overcoming barriers to creating more experience-led learning experiences for students:

- Learning and teaching champions play a vital role in driving forward change within engineering degrees. Excellent teaching and successful delivery should be recognised and rewarded by universities. Champions also come from industry.

- Academic staff, particularly those with experience of industry, make essential contributions to experience-led components within the curriculum. In recent years, the number of academic staff with prior experience in industry has been declining, particularly in research-led universities The case studies provide examples of mechanisms that enable academics to gain insight into industry including: collaborating with engineers in industry on the development of the experience-led teaching components; undertaking secondments in industry and bringing engineers from industry into universities to support teaching.

- Leaderships and commitment from senior management support to ensure that change is embedded in business plans and resources are made available.

- Both industry and the universities must commit to championing change and to developing experience-led engineering degrees. This involves committing time and energy towards building, enhancing and sustaining partnerships between industry and academia.

\section{References}

Arlett, C. \& Dales, R. 2008, Engage Project Report, The Higher Education Academy Engineering Subject Centre, Loughborough University, Loughborough, Leicestershire. 
Collins, K. \& Davies, J. 2009, "Feedback through student essay competitions: what makes a good engineering lecturer?", Engineering Education: Journal of the Higher Education Academy Engineering Subject Centre, vol. 4, no. 1, pp. 8-15.

Confederation of British Industry (CBI) 2009, Stronger together - Businesses and universities in turbulent times, CBI.

Crawley, E.F., Malmqvist, J., Ostlund, S. \& Brodeur, D. 2007, Rethinking Engineering Education: The CDIO Approach, .

de Graaff, E. \& Kolmos, A. 2007, Management of Change - Implementation of Problem-Based and Project-Based Learning in Engineering, Sense Publishers, Rotterdam, The Netherlands.

Department for Business Innovation and Skills 2009, Higher Ambitions - The future of universities in a knowledge economy.

Engineering Council UK 2008 (first published 2004), The Accreditation of Higher Education Programmes - UK Standard for Professional Engineering Competence, Engineering Council UK, London.

Hannan, A. \& Silver, H. 2002, Guide to Innovation in Teaching and Learning, LTSN Generic Centre, York.

JISC infoNet Service infoKIT - Change Management.

Lamb, F., Arlett, C., Dales, R., Ditchfield, R., Parkin, B. and Wakeham, W. 2010 Engineering Graduates for Industry, Royal Academy of Engineering, London.

Lord Sainsbury, 2007, The Race to the Top - A Review of Government's Science and Innovation Policies, HM Treasury, Norwich.

McCartan, C.D., Cunningham, G., Buchanan, F.J. \& McAfee, M. 2008, "Application of a generic curriculum change management process to motivate and excite students", Engineering Education: Journal of the Higher Education Academy Engineering Subject Centre, vol. 3, pp. $37-$ 44.

McKenzie, J., Alexander, S., Harper, C. \& Anderson, S. 2005, Dissemination, adoption and adaptation of project innovations in higher education: A report for the Carrick Institute for Learning and Teaching in Higher Education, University of Technology Sydney, Sydney.

The European High Education Area 1999, The Bologna Declaration Process - Towards the European Higher Education Area, The European High Education Area, Bologna, Italy.

The Royal Academy of Engineering 2007, Educating Engineers for the 21st Century, The Royal Academy of Engineering, London.

Trowler, P., Saunders, M. \& Knight, P. 2003, Change Thinking, Change Practices - A guide to change for Heads of Department, Programme Leaders and other change agents in Higher Education, LTSN Generic Centre, York.

Wise, C. and McCann, E. (2005) Building to learn: Constructionarium. Ingenia, issue 24, $44-49$.

\section{Acknowledgements}

The authors would like to thank all the staff at the case study institutions who gave their time to be interviewed and to contribute data and comments for the case studies. We would also like to 
acknowledge the advice and valuable contributions from the Study's Project Management Group and Oversight Committee, in particular Professor Sir William Wakeham and Dr Bob Ditchfield from the Royal Academy of Engineering. Input from lain Nixon from KSA Partnership was extremely helpful in helping the team develop the research methodology. The funding for the study came from the Department for Business, Innovation and Skills.

\section{Copyright statement}

Copyright $\odot 2010$ Carol Arlett, Fiona Lamb, Richard Dales, Liz Willis, Emma Hurdle: The authors assign to the EE2010 organisers and educational non-profit institutions a non-exclusive licence to use this document for personal use and in courses of instruction provided that the article is used in full and this copyright statement is reproduced. The authors also grant a nonexclusive licence to the Engineering Subject Centre to publish this document in full on the World Wide Web (prime sites and mirrors) on flash memory drive and in printed form within the EE2010 conference proceedings. Any other usage is prohibited without the express permission of the authors. 